Vol. 4: 513-518.

\title{
In vitro pollen culture and the regeneration of Brassica campestris L. plants
}

\author{
Yang-Dong Guo ${ }^{1}$ and Seppo Pulli \\ Agricultural Research Centre of Finland, Institute of Crop and Soil Science, FIN-31600 Jokioinen, Finland
}

\begin{abstract}
Brassica campestris (Brassica rapa L. ssp. oleifera) is an important oilseed crop, particularly in Finland. Pollen culture techniques for haploid production have been developed, but $B$. campestris is relatively recalcitrant in pollen culture. Twenty eight genotypes of $B$. campestris were included in this study. The donor plants were grown in the greenhouse and transferred to the growth cabinet before bolting. Buds (2-4 mm long) were selected, macerated in B5 medium, then NLN liquid culture medium was added. The microspores were incubated in the dark at $32^{\circ} \mathrm{C}$ for $72 \mathrm{~h}$, then at $25^{\circ} \mathrm{C}$ for a further three weeks. Nineteen genotypes produced microspore-derived embryos. The highest yield was more than 300 embryos per 100 buds. Activated charcoal $(150 \mathrm{mg} / \mathrm{L})$ promoted embryogenesis, pollen development was faster and the embryo yield was higher. Plants were regenerated after transferring embryos to a solid B5 medium. Colchicine solution was used to double the chromosome complements. About 100 regenerate plants have been obtained in our laboratory, and these haploids will be useful for the oilcrop breeding.
\end{abstract}

Key words: oilcrop, genotype, bud size, activated charcoal, donor plant condition, embryogenesis, plant regeneration

${ }^{\prime}$ Current address: Laboratory of Plant Physiology, Department of Biology, University of Turku, FIN- 20500 Turku, Finland

\section{Introduction}

Brassica campestris (Brassica rapa L. ssp. oleifera) is grown in many countries, including Finland, as an oilseed crop. It is mostly self-incompatible and therefore selfed lines are expensive and very difficult to obtain. A haploid breeding technique for the Brassica species has been developed during the past two decades. For $B$. napus, pollen culture has become a tool for crop breeding because the yield of microsporederived embryos is very high (about 900,000 per 100 buds), (Swanson et al. 1987; Kott et al. 1988; Siebel and Pauls 1989). Haploids are of considerable use in plant breeding and genetic studies. Haploid production is extremely attractive because it not only provides an opportunity to select at the haploid level in vitro for desirable agronomic and seed quality characteristics, but it also provides a means of producing genetically stable homozygous lines, fixed by chromo- 


\section{AGRICULTURAL SCIENCE IN FINLAND}

Guo, Y. \& Pulli, S.: In vitro pollen culture and the regeneration of Brassica campestris L. plants

some doubling (Kott and Beversdorf 1990). In cross-pollinating species, such as B. campestris, doubled haploids are more likely to be used as parents in the production of single- or doublecross hybrids (Dunwell 1985).

A microspore culture technique has been developed for B. campestris (Baillie et al. 1992, Burnett et al. 1992) which has a number of specific advantages over anther culture (Pierik 1987). In particular, it is more efficient for haploid production than anther culture (Siebel and Pauls 1989). Androgenesis has become the most important source of haploids produced in vitro by far. This is extremely important; as pollen grains are available in considerable quantities and each has the potential to develop into a haploid plant (Pierik 1987). B. campestris is relatively recalcitrant in pollen culture, however. The yield of embryos is relatively low and embryos can only be obtained from a few genotypes. Here we report our results on the pollen culture of B. campestris, with the aim of establishing a pollen culture system for breeding.

\section{Material and methods}

\section{Donor plant and growth conditions}

Twenty eight genotypes of $B$. campestris were tested: fourteen cultivars and fourteen breeding lines. The donor plants were grown under controlled-environment greenhouse conditions with $16 \mathrm{~h}$ photoperiod (approximately $300 \mu \mathrm{mol} / \mathrm{m}^{2} \mathrm{~s}$ ) and a day/night temperature of $25 / 15^{\circ} \mathrm{C}$. The donor plants were grown in individual $12 \mathrm{~cm}$ pots, watered daily and fertilized once a week. Before bolting, the donor plants were transferred to a growth cabinet with a $16 \mathrm{~h} / 8 \mathrm{~h}$, light/dark regime. The temperature was $10^{\circ} \mathrm{C}$ during the light period, with a light intensity of $300 \mu \mathrm{mol} /$ $\mathrm{m}^{2} \mathrm{~s}$, and $5^{\circ} \mathrm{C}$ during the dark period. The donor plants were watered every two days and fertilized once a week.

\section{Pollen culture}

Flower buds (50-75) were removed from donor plants older than 6 weeks. Bud length was 2-4 $\mathrm{mm}$, only those in this range could produce embryos. The optimum timing for microspore culture is during mid-late to very late uninucleate stage, DAPI (4', 6'-diamidino-2-phenylindol) was used to check pollen development. The buds were placed in test tubes and surface sterilized in $4.5 \%$ sodium hypochlorite with one drop of Tween-20 for $15 \mathrm{~min}$, followed by three fiveminute washes with sterile, distilled water. The buds were then macerated with a glass rod in cold B5 medium (Gamborg et al. 1968) without iron salt, supplemented with $13 \%(\mathrm{w} / \mathrm{v})$ sucrose (in $\mathrm{B} 5$ medium, $\mathrm{CaCl}_{2} \cdot 2 \mathrm{H}_{2} \mathrm{O}$ was increased to $750 \mathrm{mg} / \mathrm{L}$ ), filtered through a $48 \mu \mathrm{m}$ nylon mesh and pelleted by centrifugation at $1000 \mathrm{rpm}$ for $5 \mathrm{~min}$ in the same medium 3 times. The microspores were resuspended in the required amount of NLN medium (Lichter 1982) supplemented with $13 \%$ sucrose and $0.83 \mathrm{mg} / \mathrm{L}$ potassium iodide, but without potato extract and hormones. The final density of microspores was $5 \times 10^{4}$ per millilitre. Activated charcoal was added to some of the NLN culture medium at $150 \mathrm{mg} / \mathrm{L}$. Ten millilitres of microspore suspension was dispensed into a 100x15 mm sterile Petri dish. The dishes were then wrapped with double layers of parafilm. Every test was repeated at least three times. The microspores were incubated in the dark for an initial period of three days at $32^{\circ} \mathrm{C}$, followed by three weeks of dark culture at $25^{\circ} \mathrm{C}$.

\section{Plant regeneration}

After three weeks of microspore culture, the cotyledonous embryos were counted and placed on a slow shaker $(50 \mathrm{rpm})$ under continuous light at $25^{\circ} \mathrm{C}$ until they were green. At this time, the embryos were transferred to a solid B5 medium containing $2 \%$ sucrose and $0.3 \%$ phytagel without growth regulators (Gamborg et al. 1968) and cultured at $25^{\circ} \mathrm{C}, 16 \mathrm{~h}$ light period. Plantlets were obtained and then labeled individually. Prior to 
Vol. 4: 513-518.

transfer of plantlets to soil, the roots of the plantlets were immersed in a $0.2 \%$ colchicine solution for $3 \mathrm{~h}$ followed by several water washes. The plantlets were then potted and placed in a greenhouse under plastic cups to maintain a high humidity level.

\section{Results and discussion}

\section{Influence of genotype}

B. campestris genotype is considered to be a key factor in obtaining microspore-derived embryos; only a few genotypes can produce microsporederived embryos (Baillie et al. 1992, Burnett et al. 1992). Sorvari (1985) indicated that the highest embryo yield was from cross type "dihaploid x dihaploid" and high-glucosinolate genotypes. For B. napus, haploid production was also genotype dependent (Chuong et al. 1988). B. campestris is mostly self-incompatible and open-pollinated, genotypes are mixed to various degrees in the population. There is plant to plant variation in microspore culture response within genotypes (Ferrie and Keller 1995). In our research, from a total of 28 genotypes tested, 19 produced embryos.

\section{Influence of bud size}

Bud size plays an important role during pollen culture; microspores had embryogenic potential only during a short and specific period during pollen development. A range of bud sizes was tested: smaller than $2.0 \mathrm{~mm}, 2.0-2.9 \mathrm{~mm}, 3.0$ $3.9 \mathrm{~mm}$ and bigger than $4.0 \mathrm{~mm}$. Only the buds measuring $2.0 \mathrm{~mm}$ to $3.9 \mathrm{~mm}$ in length were easy to produce embryos. The optimum timing for microspore culture is during the mid-late to very late uninucleate stage. Optimum bud lengths were different for different genotypes; for example, the optimum bud length for Emma (approx. $3.2 \mathrm{~mm}$ ) was slightly higher than for Candle (approx. $2.8 \mathrm{~mm}$ ).
Table 1. Response of genotypes in pollen culture. Activated charcoal was contained in the culture medium. Mean is from at least 8 replicates.

\begin{tabular}{|c|c|c|}
\hline Genotype & Embryos/100 buds & SD \\
\hline Bc3059 & 326 & 64 \\
\hline Bc3158 & 283 & 77 \\
\hline Kulta & 120 & 34 \\
\hline Candle & 78 & 29 \\
\hline Bc3211 & 76 & 21 \\
\hline Bc3063 & 54 & 17 \\
\hline Bc3161 & 49 & 15 \\
\hline Bc 3230 & 36 & 9 \\
\hline Emma & 32 & 9 \\
\hline Bc3234 & 30 & 11 \\
\hline Kova & 27 & 4 \\
\hline $\mathrm{Bc} 3066$ & 23 & 9 \\
\hline Bc3139 & 15 & 9 \\
\hline Bc3131 & 13 & 7 \\
\hline Sisu & 13 & 6 \\
\hline Tobin & 11 & 8 \\
\hline Tyko & 8 & 6 \\
\hline Hian Vankka & 4 & 5 \\
\hline Bc3134 & 3 & 2 \\
\hline Bc3129 & 0 & 0 \\
\hline Bc3163 & 0 & 0 \\
\hline Bc3141 & 0 & 0 \\
\hline Turkel & 0 & 0 \\
\hline Hanne & 0 & 0 \\
\hline Nopsa & 0 & 0 \\
\hline Ww1774 & 0 & 0 \\
\hline Palle & 0 & 0 \\
\hline Vallti & 0 & 0 \\
\hline
\end{tabular}

SD: standard deviation.

\section{Effect of activated charcoal}

In some of our tests, we found that the activated charcoal was beneficial for embryogenesis. A series amount of activated charcoal was added to the liquid NLN media and $150 \mathrm{mg} / \mathrm{L}$ of activated charcoal was found the best for the microspore culture (data not presented); pollen development was faster and the yield of embryos was higher in the culture medium with activated charcoal than those in the culture medium without activated charcoal. It has been reported that endogenously produced toxins within cultures 
Guo, Y. \& Pulli, S.: In vitro pollen culture and the regeneration of Brassica campestris L. plants

Table 2. Microspore embryogenesis for various bud lengths of genotype $\mathrm{Bc} 3158$. Activated charcoal was contained in the culture medium. Mean is from at least 6 replicates.

\begin{tabular}{lcc}
\hline Bud length & Embryos/100 buds & SD \\
\hline$<2.0 \mathrm{~mm}$ & 0 & 0 \\
$2.0-2.9 \mathrm{~mm}$ & 203 & 79 \\
$3.0-3.9 \mathrm{~mm}$ & 77 & 18 \\
$>4.0 \mathrm{~mm}$ & 2 & 2 \\
\hline
\end{tabular}

SD: standard deviation.

play a negative role in the initiation and development of embryos in B. napus (Kott et al. 1988). High levels of phenylacetic acid and $p$-OH-benzoic acid have been found in Daucus cultures; 2,6-OH-enzoic acid and benzoic acid have been found in Allium cultures; benzoic acid, pelargonic acid and caprylic acid have been found in Haplopappus cultures (Fridborg et al. 1978). It was also shown that $p-\mathrm{OH}$-benzoic acid had inhibitory effects on the embryogenesis in Daucus cultures (Fridborg et al. 1978), whereas the media with activated charcoal did not. This evidence suggests that activated charcoal adsorbs such toxins. We noted that, in the absence of activated charcoal, cell division, embryo formation and development were inhibited in the culture. Often there was no growth or development in vitro; or initial growth was followed by the abortion of embryos. When activated charcoal was added to the media, such effects were no longer apparent, the reason is perhaps due to interference with polyphenolic compounds produced by the explants and partial adsorption of the exogenous auxin by the activated charcoal (Dumas and Monteuuis 1995). In our work, the embryos obtained from microspore culture with activated charcoal and microspore culture without activated charcoal are normal developed, and both of them have the potential to develop to the plantlets. For the microspore culture of Brassica species, media change was considered a good method to enhance embryo yield (Baillie et al. 1992, Burnett et al. 1992, Hansen and Svinnset 1993). There is no toxin in the fresh medium, so the pollen can develop well in the new medium.

\section{Donor plant conditions}

For pollen cultures of the Brassica species, donor plant conditions are also an important factor in embryo production. In our work, the donor plants were tested with different lengths of exposure to low temperatures. The plants were grown in a controlled-environment greenhouse $\left(25 / 15^{\circ} \mathrm{C}, 16 \mathrm{~h}\right.$ lightperiod), before bolting (about 6 weeks), they were then transferred to the growth cabinet $\left(10 / 5{ }^{\circ} \mathrm{C}, 16 \mathrm{~h}\right.$ lightperiod). We established that embryo yield was directly proportional to the length of the low temperature pre-treatment, not to the age of donor plants. The yield of embryo was similar, not significantly different if buds were moved from 6th week to 9 th or 10 th week (data not presented). Baillie et al. (1992) recommended a low temperature pretreatment for donor plants. The temperature in the growth cabinet was lower and more stable than it was in the greenhouse, and this benefited the plants. Low temperature pre-treatment has become usual in the haploid breeding of cereal crops (Nitsch, 1972; Wang et al. 1974).

We also established that embryos could only be produced from older plants. The donor plants were transferred into a growth cabinet (10/ $5^{\circ} \mathrm{C}, 16 \mathrm{~h}$ lightperiod) after six weeks growth in the greenhouse. The too young donor plants failed to produce embryos (data not presented). Burnett et al. (1992) also showed that four to five week old plants did not produce embryos. For B. napus, microspores isolated from the buds of older plants had a higher embryo yield than those of the younger ones (Takahata et al. 1991).

Table 3. Effect of activated charcoal (AC). Mean is from at least 8 replicates.

\begin{tabular}{lcc}
\hline Genotype & $\begin{array}{c}\text { Em / } 100 \text { buds } \pm \text { SD } \\
\text { with AC }\end{array}$ & $\begin{array}{c}\text { Em/100 buds } \pm \text { SD } \\
\text { without AC }\end{array}$ \\
\hline Bc3158 & $196 \pm 65$ & $69 \pm 32^{*}$ \\
Kulta & $101 \pm 16$ & $52 \pm 12^{*}$ \\
\hline
\end{tabular}

SD: standard deviation.

* Significant at $1 \%$ level. 
Vol. 4: 513-518.

Table 4. Effect of cold treatment. Activated charcoal was contained in the culture medium. Mean is from at least 6 replicates.

\begin{tabular}{lcc}
\hline Genotype & Cold treatment week(s) & Em/100 buds \pm SD \\
\hline Bc3059 & 0 (control) & $61 \pm 23^{\mathrm{c}}$ \\
1 & $172 \pm 47^{\mathrm{ab}}$ \\
2 & $194 \pm 35^{\mathrm{ab}}$ \\
3 & $264 \pm 53^{\mathrm{a}}$ \\
Kulta & $\#$ & \\
& 0 & $40 \pm 17^{\mathrm{f}}$ \\
& 1 & $77 \pm 43^{\mathrm{d}}$ \\
& 2 & $62 \pm 21^{\mathrm{de}}$ \\
3 & $63 \pm 29^{\mathrm{de}}$ \\
4 & $74 \pm 27^{\mathrm{d}}$ \\
\hline
\end{tabular}

\# Plants ceased to produce buds.

SD: standard deviation.

Means followed by the same letter are not significantly different according to the Duncan multiple range test at the $5 \%$ level.
The microspore culture technique for Brassica species has existed for some years, and currently the microspore culture technique for B. napus is very successful as a breeding tool. The yield of embryos from $B$. campestris is relatively poor, however. To improve the microspore cultures for $B$. campestris breeding, it is important to enhance the yield of embryos. The effect of several factors including optimal media, donor plant conditions and culture temperature will be tested in the future.

Acknowledgements. We wish to thank Mr. Veli-Matti Rokka for his valuable discussions. Some seeds were kindly provided by Mr. Juha Vilkki. Thanks are also due to Dr. Jonathan Robinson for reviewing the manuscript. The research work is supported by The Ministry of Agriculture \& Forestry of Finland and The Agricultural Research Centre of Finland.

\section{References}

Baillie, A.M.R., Epp, D.J., Hutcheson, D. \& Keller, W.A. 1992. In vitro culture of isolated and regeneration of plants in Brassica campestris. Plant Cell Reports 11: 234-237. Burnett, L., Yarrow, S. \& Huang, B. 1992. Embryogenesis and plant regeneration from isolated microspores of Brassica rapa L. ssp. oleifera. Plant Cell Reports 11: 215-217.

Chuong, P.V., Deslauriers, C., Kott, L.S. \& Beversdorf, W.D. 1988. Effects of donor genotype and bud sampling on microspore culture of Brassica napus. Canadian Journal of Botany 66: 1653-1657.

Dumas, E. \& Monteuuis, O. 1995. In vitro rooting of micropagated shoots from juvenile and mature Pinus pinaster explants: influence of activated charcoal. Plant Cell, Tissue and Organ Culture 40: 231-235.

Dunwell, J.M. 1985. Haploid Cell Culture. In: Dixon, R.A. (ed.). Plant cell culture. Oxford, Washington DC. p. 21. Ferrie, A.M.R. \& Keller, W.A. 1995. Development of methodology and applications of doubled haploids in Brassica rapa. Proceedings of the 9th International Rapeseed Congress, G35. Cambridge, UK. p. 807-809.

Fridborg, G., Pedersen, M., Landström, L. \& Eriksson, T. 1978. The effect of activated charcoal on tissue culture: Adsorption of metabolites inhibiting morphogenesis. Physiologia Plantarum 43: 104-106.

Gamborg, O.L., Miller, R.A. \& Ojima, K. 1968. Nutrient requirements of suspension cultures of soybean root cells. Experimental Cell Research 50: 151-158.
Hansen, M. \& Svinnset, K. 1993. Microspore culture of Swede (Brassica napus ssp. rapifera) and the effects of fresh and conditioned media. Plant Cell Reports 12: 496500.

Kott, L.S., Polsoni, L. \& Beversdorf, W.D. 1988. Preand postmitotic cytological evens in isolated microspore culture of Brassica napus. Canadian Journal of Botany 66: 1658-1664.

- \& Beversdorf, W.D. 1990 Enhanced plant regeneration from microspore-derived embryos of Brassica napus by chilling, partial desiccation and age selection. Plant Cell, Tissue and Organ Culture 23: 187-192.

Lichter, R. 1982. Induction of haploid plants from isolated pollen of Brassica napus. Zeitschrift für Pflanzenphysiologie 105: 427-434.

Nitsch, J.P. 1972. Haploid plants from pollen. Zeitschrift Pflanzenzüchtg 67: 3-18.

Pierik, R.L.M. 1987. In Vitro Culture of Higher Plants. Martinus Nijhoff Publishers, Dordrecht. p. 243-244.

Siebel, J. \& Pauls, K.P. 1989. A comparison of anther and microspore culture as a breeding tool in Brassica napus. Theoretical and Applied Genetics 78: 473-479. Sorvari, S. 1985. Production of haploids from anther culture in agriculturally valuable Brassica campestris $\mathrm{L}$. cultivars. Annales Agriculturae Fenniae 24: 149-160.

Swanson, E.B., Coumans, M.P., Wu, S.C., Barsby T.L. \& Beversdorf, W.D. 1987. Efficient isolation of microspores and the production of microspore-derived embryos 
Guo, Y. \& Pulli, S.: In vitro pollen culture and the regeneration of Brassica campestris L. plants

from Brassica napus. Plant Cell Reports 6: 94-97.

Takahata, Y., Brown, D.C.W. \& Keller, W.A. 1991. Effect of donor plant age and inflorescence age on microspore culture of Brassica napus L. Euphytica 58: 51-55.
Wang, C.C., Sun, C.S. \& Chu, Z.C. 1974. On the conditions for the induction of rice pollen plantlets and certain factors affecting the frequency of induction. Acta Botanica Sinica 16: 43-53.

\title{
SELOSTUS
}

\section{Kevätrypsin mikrosporiviljely in vitro ja vihreiden kasvien tuottaminen alkioista}

\author{
Yang-Dong Guo ja Seppo Pulli \\ Maatalouden tutkimuskeskus
}

Tutkimus sisälsi 28 perimältään erilaista kevätrypsilinjaa ja -lajiketta. Tutkimusmateriaali kasvatettiin alkuvaiheessa kasvihuoneessa ja siirrettiin ennen kukintaa kasvatuskammioon. Mikrosporiviljelyssä parhaan tuloksen tuottivat mikrosporit eli epäkypsät siitepölyhiukkaset, joiden kehitysvaihe oli myöhäinen 1-tumavaihe, mikä edellyttää, että kukkasilmun pituus on $2-4 \mathrm{~mm}$. Oikeassa kehitysvaiheessa olevat kukkasilmut murskattiin B5-nestealustalla ja mikrosporit viljeltiin NLN-nestealustalla, ensin $72 \mathrm{~h}$ ajan $+32^{\circ} \mathrm{C}$ :ssa ja seuraavaksi kolme viikkoa $+25^{\circ} \mathrm{C}$ :ssa. Viljellyistä mikrosporeista alkioita tuotti yhdeksäntoista kevätrypsigenotyyppiä. Parhaalla genotyypillä saatiin 100 mikrosporista 300 alkiota. Aktiivihiili 150 $\mathrm{mg} / \mathrm{l}$ paransi mikrosporien kehitystä ja lakionmuodostusta sekä lisäsi alkioiden lukumäärää. Alkiot kasvatettiin vihreiksi kasveiksi kiinteällä B5-alustalla. Tutkimuksen ensimmäinen vaihe tuotti noin 100 haploidista kevätrypsikasvia. 